May 2000 • NREL/CP-590-28323

\title{
Qualification Standard for Photovoltaic Concentrator Modules
}

R. McConnell and S. Kurtz

National Renewable Energy Laboratory - Golden, Colorado

W.R. Bottenberg

Photovoltaics International, LLC - Sunnyvale, California

R. Hammond

Photovoltaic Testing Laboratory - Mesa, Arizona

S.W. Jochums

Underwriters Laboratories, Inc. - Northbrook, Illinois

A.J. McDanal

ENTECH, Inc. - Keller, Texas

D. Roubideaux

Amonix Inc. - Torrance, California

C. Whitaker

Endecon Engineering - San Ramon, California

J. Wohlgemuth

BP Solarex - Frederick, Maryland

Presented at the $16^{\text {th }}$ European Photovoltaic Solar Energy Conference and Exhibition Glasgow, Scotland, U.K. May 1-5, 2000

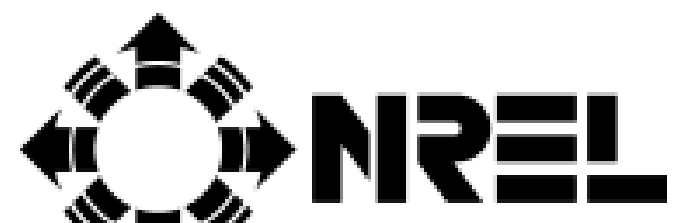

National Renewable Energy Laboratory

1617 Cole Boulevard

Golden, Colorado 80401-3393

NREL is a U.S. Department of Energy Laboratory

Operated by Midwest Research Institute $\bullet$ Battelle $\bullet$ Bechtel

Contract No. DE-AC36-99-G010337 


\section{NOTICE}

The submitted manuscript has been offered by an employee of the Midwest Research Institute (MRI), a contractor of the US Government under Contract No. DE-AC36-99G010337. Accordingly, the US Government and MRI retain a nonexclusive royalty-free license to publish or reproduce the published form of this contribution, or allow others to do so, for US Government purposes.

This report was prepared as an account of work sponsored by an agency of the United States government. Neither the United States government nor any agency thereof, nor any of their employees, makes any warranty, express or implied, or assumes any legal liability or responsibility for the accuracy, completeness, or usefulness of any information, apparatus, product, or process disclosed, or represents that its use would not infringe privately owned rights. Reference herein to any specific commercial product, process, or service by trade name, trademark, manufacturer, or otherwise does not necessarily constitute or imply its endorsement, recommendation, or favoring by the United States government or any agency thereof. The views and opinions of authors expressed herein do not necessarily state or reflect those of the United States government or any agency thereof.

Available electronically at http://www.doe.gov/bridge

Available for a processing fee to U.S. Department of Energy and its contractors, in paper, from:

U.S. Department of Energy

Office of Scientific and Technical Information

P.O. Box 62

Oak Ridge, TN 37831-0062

phone: 865.576 .8401

fax: 865.576.5728

email: reports@adonis.osti.gov

Available for sale to the public, in paper, from:

U.S. Department of Commerce

National Technical Information Service

5285 Port Royal Road

Springfield, VA 22161

phone: 800.553 .6847

fax: 703.605.6900

email: orders@ntis.fedworld.gov

online ordering: http://www.ntis.gov/ordering.htm

Printed on paper containing at least $50 \%$ wastepaper, including $20 \%$ postconsumer waste 


\title{
QUALIFICATION STANDARD FOR PHOTOVOLTAIC CONCENTRATOR MODULES
}

\author{
Robert McConnell and Sarah Kurtz
}

NREL, 1617 Cole Boulevard, Golden, CO 80401-3393, TEL: 303-384-6419, 303-384-6475, FAX: 303-384-6481, 303-384-

6531, e-mail: robert_mcconnell@nrel.gov, sarah_kurtz@nrel.gov

William R. Bottenberg

Photovoltaics International, LLC, 171 Commercial Street, Sunnyvale, CA 94086, TEL: 408-731-1207, FAX: 408-746-3890, e-mail: wbotttenberg@pvintl.com

Robert Hammond

Photovoltaic Testing Laboratory, Arizona State University EAST, 7349 E. Unity Ave., Mesa, AZ 85212, TEL: 480-727-

1221, FAX: 480-727-1223, e-mail: b.hammond@asu.edu

Steven W. Jochums

Underwriters Laboratories, Inc., Engineering Services, 413M, 333 Pfingsten Road, Northbrook, IL 60062, TEL: 847-272-

8800 x42229, FAX: 847-272-9718, e-mail: steven.jochums@us.ul.com

$$
\text { A. J. McDanal }
$$

ENTECH Inc., 1077 Chisolm Trail, Keller TX 76248, TEL: 817-379-0100, FAX: 817-379-0300, e-mail:

ajmcdanal@entechsolar.com

David Roubideaux

Amonix Inc., 3425 Fujita Street, Torrance, CA 90505-4018, TEL: 310-325-8091, FAX: 310-325-0771, e-mail:

dave@amonix.com

Charles Whitaker

Endecon Engineering, 2500 Old Crow Canyon, Suite 22, San Ramon, CA 94583, TEL: 925-552-1330, FAX: 925-552-1333, e-mail: Chuckw@endecon.com

John Wohlgemuth

BP Solarex, 630 Solarex Court, Frederick, MD 2170, TEL: 301-698-4375, FAX: 301-698-4201, e-mail:

JWOHLGEMUTH@Solarex.com

\begin{abstract}
The paper describes a proposed qualification standard for photovoltaic concentrator modules. The standard's purpose is to provide stress tests and procedures to identify any component weakness in photovoltaic concentrator modules intended for power generation applications. If no weaknesses are identified during qualification, both the manufacturer and the customer can expect a more reliable product. The qualification test program for the standard includes thermal cycles, humidity-freeze cycles, water spray, off-axis beam damage, hail impact, hot-spot endurance, as well as electrical tests for performance, ground continuity, isolation, wet insulation resistance, and bypass diodes. Because we can't verify concentrator module performance using solar simulator and reference cell procedures suitable for flat-plate modules, the standard specifies an outdoor I-V test analysis allowing a performance comparison before and after a test procedure. Two options to this complex analysis are the use of a reference concentrator module for side-by-side outdoor comparison with modules undergoing various tests and a dark I-V performance check.
\end{abstract}

Keywords: Qualification and Testing - 1: Concentrator - 2: Reliability - 3

\section{BACKGROUND}

In 1997, an IEEE working group began developing a qualification standard for photovoltaic concentrator modules as a result of industry concern that the lack of a standard was affecting the marketing and sales of their products [1]. The first draft was based on evaluation tests developed in the late 1980s at Sandia National Laboratories and published in a Sandia report in 1992 [2]. It followed the general outline of tests in the IEC Standard 61215 and the IEEE standard 1262-1995 for flat-plate modules $[3,4]$. These flat-plate standards, the result of more than a decade of module and standards development, have contributed greatly to the present level of flat-plate module reliability such that manufacturers can back their products with guarantees as long as 25 years [5].

Since the publication of these earlier documents, photovoltaic materials technology and concentrator module development have advanced. Efforts in module reliability research have produced a better understanding of known and potential failure mechanisms associated with photovoltaic concentrator modules, especially regarding the effects of moisture ingress. The results of these efforts and experience gained have been used in formulating new tests and modifying earlier tests for a proposed concentrator qualification standard.

In following the outline of tests for flat-plate module standards, the working group identified some fundamental differences between the two technologies that required significantly different test approaches. Most flat-plate modules have a thin two-dimensional geometry, whereas concentrator modules usually have optics that are mounted away from the cells, forming a three-dimensional structure. As a result, one major difference between flatplate standards and the proposed concentrator standard is that the concentrator standard has parallel test sequences for concentrator receivers and modules. A receiver is defined as an assembly of one or more PV cells that accepts concentrated sunlight and incorporates the means for thermal and electrical energy removal. A module is the smallest, complete, environmentally protected assembly of receivers and optics and related components, such as interconnects and mounting, that accepts unconcentrated sunlight. Figure 1 shows two linear concentrator modules and an associated receiver. Another significant deviation from the flat-plate standards arises 
from the difficulty in measuring performance after a test sequence because most concentrator modules cannot be accurately characterized with solar simulators. Later in the paper, we will discuss proposed power conversion efficiency tests, as well as two optional performance checks, to replace the use of indoor simulators.

All tests and procedures in this paper are under consideration by the IEEE working group. We plan to ballot on the proposed standard later this year, in hopes of reaching a consensus for the final standard. We have submitted an earlier draft for consideration by an International Electrotechnical Commission working group, as a proposed international qualification standard.

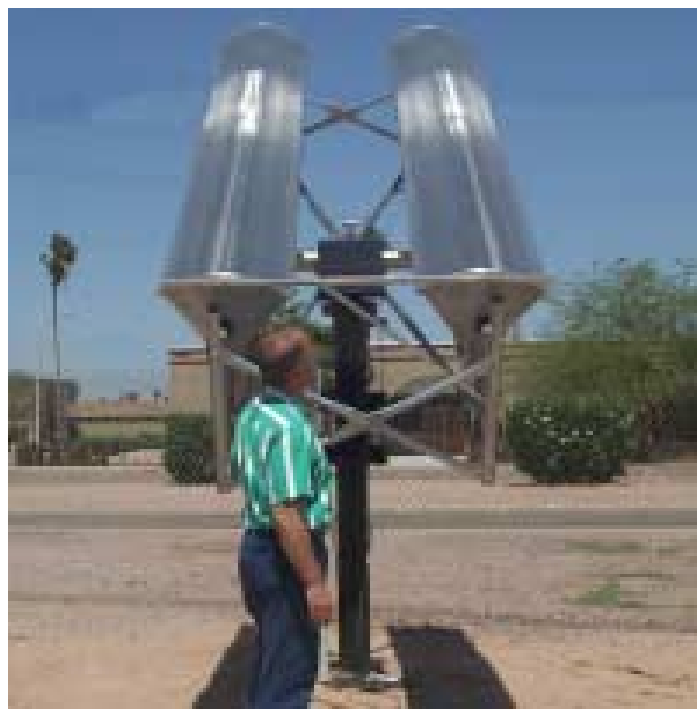

(a)

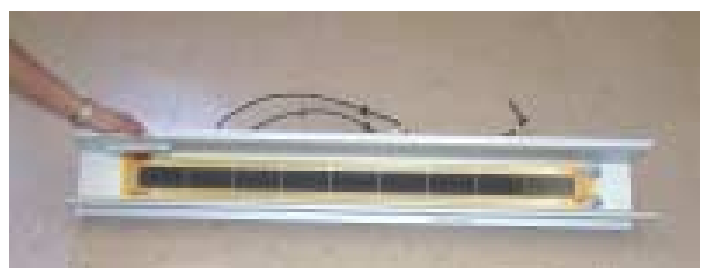

(b)

Figure 1. a) Two linear concentrator modules ready for qualification standard testing, at the Photovoltaic Testing Laboratory at Arizona State University East. receiver for the linear concentrator receiver tests.

\section{OVERVIEW OF QUALIFICATION TEST PROGRAM}

Figure 2 shows the proposed test program in the most recent draft (April 2000) of the proposed standard. It requires 7 receivers, 5 modules, and, for a receiver design with inaccessible bypass diodes, 1 specially constructed receiver. Details for the temperature extremes, exposure duration, isolation determinate procedures, etc., are in the latest draft of the standard. In this paper, we will only discuss each sequence in general terms that will still, in many cases, contain tests similar to flat-plate qualification tests. Many of these tests are based on ASTM standards [6].

\subsection{Baseline}

Referring to Figure 2, we propose baseline tests for electrical performance, ground continuity, electrical isolation, and wet insulation resistance, along with visual inspections to determine the initial status of the modules and receiver sections.

\subsection{Sequence A}

In this sequence, we specify a test for bypass diodes and a thermal cycle test for two receivers.

\subsection{Sequence B}

Sequence B specifies thermal cycle tests different from that in Sequence A and humidity-freeze tests for two receivers and with parallel tests for two modules involving thermal cycling, humidity-freeze, electrical isolation, and terminations.

\subsection{Sequence C}

Here, we recommend damp heat exposure for two receivers, followed by a test for electrical isolation.

\subsection{Sequence D}

This sequence involves several module stress tests, including outdoor exposure, water spray, off-axis beam damage, hail impact, and hot-spot endurance.

2.6 Sequence E

For receivers in which the by-pass diodes are inaccessible, we specify a specially prepared receiver having access to diodes for a bypass diode test.

\subsection{Final Test and Inspections}

All modules and receivers are subjected to final tests of visual inspection, electrical performance, electrical isolation, wet-insulation resistance and ground continuity.

\section{ELECTRICAL PERFORMANCE TESTS}

A critical question after many stress tests is the performance of the photovoltaic concentrator module or receiver. In the case of flat-plate photovoltaic modules, a solar simulator and reference cell provides a means to verify performance after a stress test. Photovoltaic concentrator modules, however, are critically dependent on the concentrated light incident on the receivers (See Figure 1). We have developed three possible tests to verify any degradation in the performance of modules and receivers. One of these is described in more detail in another presentation at this conference [7]. The testing organization conducts baseline outdoor performance tests under various temperature and solar irradiance conditions while measuring output currents and voltages to obtain an analytical expression for the module and receiver performance. After a stress test or series of tests, the module is again measured outdoors, and its performance, under conditions encompassed by the analysis parameters, is compared with that predicted by the analytical expression for the module's performance. It takes a lot of time to determine the analytical equation for the module's performance, so we explored two other possible determinations of any module performance degradation. 


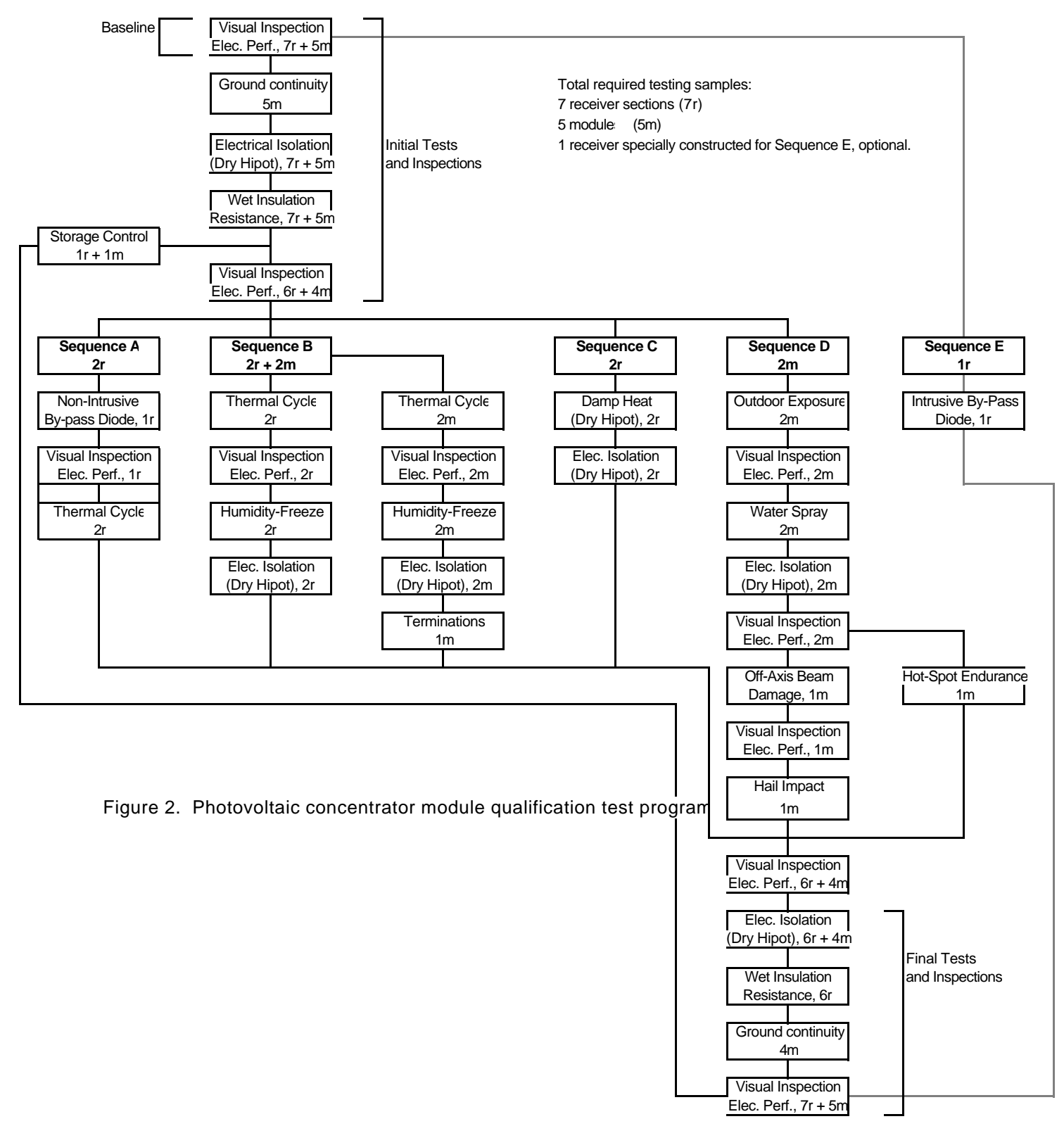


A second possible test for characterizing module performance uses a reference module. This module is not subjected to any stress tests, and its performance is measured along with all other test modules. After a module is subjected to a test sequence, its performance is again compared with that of the reference module to determine any degradation.

The third possible test for identifying degradation in modules is the use of dark current-voltage (I-V) measurements before and after intermediate stress tests. This procedure, as well as the use of a reference module, provides simpler means for determining module and receiver performance degradation resulting from increases in series resistance or breaking of connections. It is not intended to be used as the criterion for passing the final tests.

\section{CONCLUSION}

For almost three years, we have been developing a set of test procedures to qualify photovoltaic concentrator modules as reliable products in the marketplace. In building upon the considerable experience in flat-plate standards, we had to explore alternative test procedures because of fundamental differences between the two photovoltaic technologies. The most significant differences are the need for testing of the receiver separately from the module and the much large size of a typical module, necessitating the development of new procedures for identifying performance degradation after stress testing. While the details of the tests and procedures are under consideration by the IEEE working group, we plan to ballot on the proposed standard later this year in hopes of reaching a consensus for the final standard. We have submitted a draft of this qualification standard for consideration by an International Electrotechnical Commission working group as a proposed international standard.

\section{ACKNOWLEDGMENT}

We wish to acknowledge Mark Jackson, previously with ENTECH, Inc., Alex Maish at Sandia National Laboratories, and Liang Ji from the Photovoltaic Testing Laboratory at Arizona State University East, for substantial contributions to the standard's development. NREL's coordination of the standard's development was supported by DOE under Contract No. DE-AC3699GO10337.

\section{REFERENCES}

[1] IEEE Concentrator Standards Working Group, IEEE 1513/Draft8, (2000)

[2] J. R. Woodworth, M. L. Whipple, SANDIA Report, SAND92-0958, (1992)

[3] International Electrotechnical Commission, International Standard 61215, (1993)

[4] Institute of Electrical and Electronic Engineers, IEEE Standard 1262-1995, (1995)

[5] J. W. Bishop, J. Sachau, W. Zaaiman, Proceedings $2^{\text {nd }}$ World Conference and Exhibition on Photovoltaic Solar Energy Conversion, European Commission (1999) 1920.

[6[ American Society for Testing and Materials, Section 12, (1999).

[7] W. Bottenberg, Proceedings $16^{\text {th }}$ European Photovoltaic Solar Energy Conference and Exhibition, (2000) 


\section{REPORT DOCUMENTATION PAGE}

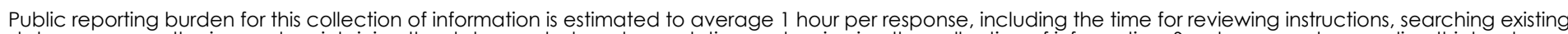

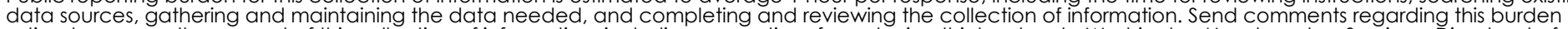

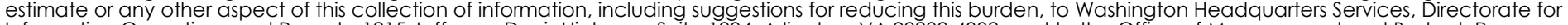

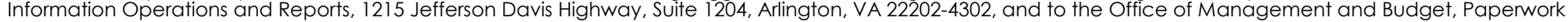
Reduction Project (0704-0188), Washington, DC 20503.

\begin{tabular}{|l|l|l|l|}
\hline 1. AGENCY USE ONLY (Leave blank) & $\begin{array}{l}\text { 2. REPORT DATE } \\
\text { May } 2000\end{array}$ & $\begin{array}{l}\text { 3. REPORT TYPE AND DATES COVERED } \\
\text { conference paper }\end{array}$ \\
\hline
\end{tabular}

4. TITLE AND SUBTITLE

Qualification Standard for Photovoltaic Concentrator Modules

6. AUTHOR(S)

Robert McConnell, Sarah Kurtz, William R. Bottenberg, Robert Hammond, Steven W. Jochums, A. J. McDanal, David Roubideaux, Charles Whitaker, John Wohlgemuth

7. PERFORMING ORGANIZATION NAME(S) AND ADDRESS(ES)

\section{FUNDING NUMBERS}

C

TA: PV002601

8. PERFORMING ORGANIZATION REPORT NUMBER

9. SPONSORING/MONITORING AGENCY NAME(S) AND ADDRESS(ES) National Renewable Energy Laboratory

1617 Cole Blvd.

Golden, CO 80401-3393 AGENCY REPORT NUMBER

CP-520-28323

11. SUPPLEMENTARY NOTES

12a. DISTRIBUTION/AVAILABILITY STATEMENT

12b. DISTRIBUTION CODE

National Technical Information Service

U.S. Department of Commerce

5285 Port Royal Road

Springfield, VA 22161

13. ABSTRACT (Maximum 200 words)

The paper describes a proposed qualification standard for photovoltaic concentrator modules. The standard's purpose is to provide stress tests and procedures to identify any component weakness in photovoltaic concentrator modules intended for power generation applications. If no weaknesses are identified during qualification, both the manufacturer and the customer can expect a more reliable product. The qualification test program for the standard includes thermal cycles, humidity-freeze cycles, water spray, off-axis beam damage, hail impact, hot-spot endurance, as well as electrical tests for performance, ground continuity, isolation, wet insulation resistance, and bypass diodes. Because we can't verify concentrator module performance using solar simulator and reference cell procedures suitable for flat-plate modules, the standard specifies an outdoor I-V test analysis allowing a performance comparison before and after a test procedure. Two options to this complex analysis are the use of a reference concentrator module for side-by-side outdoor comparison with modules undergoing various tests and a dark I-V performance check.

14. SUBJECT TERMS

photovoltaics ; qualification and testing; concentrator ; reliability

15. NUMBER OF PAGES

16. PRICE CODE

17. SECURITY CLASSIFICATION

OF REPORT

Unclassified
18. SECURITY

CLASSIFICATION

OF THIS PAGE

Unclassified
19. SECURITY CLASSIFICATION

OF ABSTRACT

Unclassified
20. LIMITATION OF ABSTRACT

UL 